\title{
URGENSI KEHADIRAN HUKUM KELUARGA DI ACEH*
}

\author{
Jamaluddin**, Faisal ${ }^{* * * *}$ dan Nanda Amalia**** \\ Bagian Hukum Perdata, Fakultas Hukum Universitas Malikussaleh \\ Komplek Kampus Bukit Indah, Jalan Jawa, Lhokseumawe Provinsi Aceh
}

\begin{abstract}
A valid marriage according to the religion, but not legal under state law led to marriage is not legal protection, so that the rights are owned by the family unprotected. Additionally, family law arrangements are still voluntary, can cause difficulties in realizing the goal of law that works to protect the rights of every person in family relationships. The issue of family law at the present time needs serious and comprehensive arrangement, namely the presence of family law in Aceh. Family law has a crucial role in regulating the various issues ranging from the establishment of a family to provide guarantees for the fulfillment of the rights possessed by each member of the family.
\end{abstract}

Keywords: urgency, family law, Aceh.

\section{Intisari}

Perkawinan yang sah menurut agama tetapi tidak sah menurut hukum negara menyebabkan perkawinan tidak mendapatkan perlindungan hukum, sehingga hak-hak yang dimiliki oleh keluarga tidak terlindungi. Selain itu, pengaturan hukum keluarga yang masih bersifat fakultatif dapat menyebabkan kesulitan dalam mewujudkan tujuan hukum yang berfungsi untuk melindungi hak-hak yang dimiliki oleh setiap orang dalam hubungan keluarga. Persoalan hukum keluarga pada masa kini perlu pengaturan secara serius dan komprehensif, yakni kehadiran Hukum Keluarga di Aceh. Hukum keluarga memiliki peranan yang krusial dalam mengatur berbagai permasalahan mulai dari pembentukan sebuah keluarga hingga memberikan jaminan atas terpenuhinya hak-hak yang dimiliki oleh masing-masing anggota keluarga.

Kata Kunci: urgensi, hukum keluarga, Aceh.

\section{Pokok Muatan}

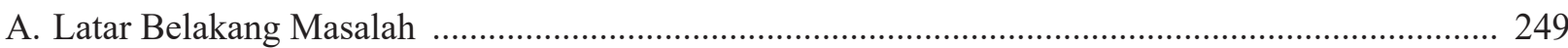

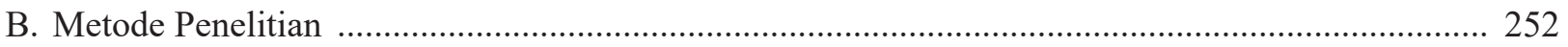

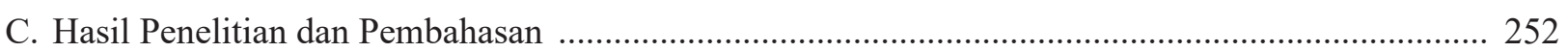

1. Fenomena Permasalahan Hukum Keluarga di Aceh ................................................................ 252

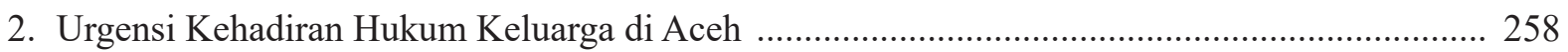

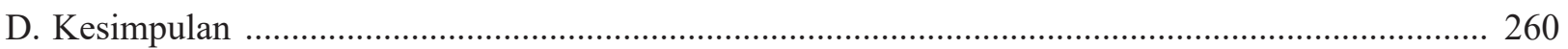

\footnotetext{
Artikel ini dibuat berdasarkan hasil penelitian dari Skema Penelitian Unggulan Perguruan Tinggi (PUPT), dalam bidang unggulan Aspek Hukum Dalam Masyarakat (Kajian Atas Keberlakuan Hukum), yang didanai oleh DITLITABMAS - RISTEKDIKTI Tahun 2016.

** Alamat korespondensi: jamaluddin449@yahoo.com.

**** Alamat korespondensi: faichal_fh@yahoo.co.id.

*****Alamat korespondensi: nandaamalia2303@gmail.com.
} 


\section{A. Latar Belakang Masalah}

Berbicara tentang hukum maka berkaitan dengan asas (prinsip), kaedah (norma) dan aturan konkrit yang mengatur berbagai aspek kehidupan manusia agar hidup tertib, aman, dan damai, baik di lingkungan keluarga, masyarakat, bangsa, dan negara. Hukum adalah peraturan yang dibuat penguasa (pemerintah) atau adat yang berlaku bagi semua orang dalam masyarakat, berupa undangundang, peraturan, dan sebagainya untuk mengatur pergaulan hidup masyarakat sebagai patokan. ${ }^{1}$ Tujuan hukum untuk melindungi hak-hak yang dimiliki oleh setiap orang dalam berbagai aspek kehidupan keluarga. Hukum yang dibuat oleh pemerintah untuk mengatur kepentingan privat lebih bersifat fakultatif, sementara yang mengatur kepentingan publik lebih bersifat imperatif.

Masyarakat dalam suatu wilayah terbentuk dari keluarga. Keluarga dalam arti sempit terdiri dari suami sebagai kepala keluarga, isteri sebagai ibu rumah tangga dan anak-anak sebagai anggota keluarga yang berkumpul dan bertempat tinggal di suatu tempat dalam keadaan saling ketergantungan. Keluarga dalam arti luas apabila dalam suatu tempat tinggal itu berdiam pula pihak lain sebagai akibat adanya perkawinan, maka terjadilah kelompok anggota keluarga yang terdiri dari orang-orang yang mempunyai hubungan karena perkawinan dan karena pertalian darah. Keluarga dalam arti luas terdapat dalam masyarakat. ${ }^{2}$

Suatu keluarga terbentuk karena adanya perkawinan. Perkawinan adalah ikatan lahir batin antara seorang pria dengan seorang wanita untuk membentuk keluarga bahagia dan kekal berdasarkan
Ketuhanan Yang Maha Esa. Untuk adanya unifikasi hukum dan menjamin kepastian hukum dalam bidang hukum keluarga, maka Eksekutif bersama Legislatif sejak tahun 1974 telah menerbitkan UU No. 1 Tahun 1974 tentang Perkawinan dan UU No. 7 Tahun 1989 tentang Peradilan Agama yang telah disempurnakan dengan UU No. 50 Tahun 2009. Eksekutif juga telah menerbitkan Kompilasi Hukum Islam (KHI) melalui Instruksi Presiden No. 1 Tahun 1991 yang khusus berlaku bagi orang-orang yang beragama Islam.

Keberadaan UU No. 1 Tahun 1974 maupun UU No. 50 Tahun $2009^{3}$ dan Kompilasi Hukum Islam (KHI) telah mengatur berbagai ketentuan hukum yang berhubungan dengan hukum keluarga. Hukum keluarga sebagaimana tercantum dalam undangundang perkawinan memberikan pengaturan bahwa, "Perkawinan adalah sah, apabila dilakukan menurut hukum masing-masing agamanya dan kepercaannya itu." "Hal ini juga diatur dalam KHI yang menyatakan "Perkawinan adalah sah apabila dilakukan menurut hukum Islam sesuai dengan Pasal 2 Ayat (1) UU No. 1 Tahun 1974 tentang Perkawinan". ${ }^{5}$ Hal itu dilakukan agar terjamin ketertiban perkawinan bagi masyarakat Islam setiap perkawinan harus dicatat, ${ }^{6}$ dan pencatatan perkawinan tersebut dilakukan oleh Pegawai Pencatat Nikah.?

Perkawinan hanya dapat dibuktikan dengan Akta Nikah yang dibuat oleh Pegawai Pencatat Nikah. ${ }^{8}$ Perkawinan yang tidak dapat dibuktikan dengan Akta Nikah, dapat mengajukan itsbat nikah ke Pengadilan Agama. ${ }^{9}$ Itsbat nikah yang diajukan ke Pengadilan Agama mengenai hal-hal yang berkenaan, yaitu: ${ }^{10}$

\footnotetext{
Asep Saepudin Jahar, et al., 2013, Hukum Keluarga, Pidana, dan Bisnis, Kencana Prenadamedia Group, Jakarta, hlm. 10. Abdulkadir Muhammad, 2010, Hukum Perdata Indonesia, Citra Aditya Bakti, Bandung, hlm. 63.

Undang-Undang Nomor 50 Tahun 2009 tentang Pelayanan Publik merupakan perubahan kedua atas Undang-undang Nomor 7 Tahun 1989 tentang Peradilan Agama (Lembaran Negara Republik Indonesia Tahun 2009 Nomor 159, Tambahan Lembaran Negara Republik Indonesia Nomor 5078)

Pasal 2 ayat (1) Undang-Undang Nomor 1 Tahun 1974 tentang Perkawinan (Lembaran Negara Republik Indonesia Tahun 1974 Nomor 1, Tambahan Lembaran Negara Republik Indonesia Nomor 3019).

Pasal 4 Kompilasi Hukum Islam.

Pasal 5 ayat (1) yaitu agar terjamin ketertiban perkawinan bagi masyarakat Islam setiap perkawinan harus dicatat.

Pasal 5 ayat (2) yaitu pencatatan perkawinan tersebut pada ayat (1), dilakukan oleh Pegawai Pencatat Nikah sebagaimana yang diatur dalam Undang-Undang No. 22 Tahun 1946 tentang Pencatatan Nikah jo Undang-undang No. 32 Tahun 1954 tentang Penetapan Berlakunya UndangUndang Republik Indonesia Tanggal 21 Nopember 1946 Nomor 22 Tahun 1946 tentang Pencatatan Nikah, Talak Dan Rujuk Di Seluruh Daerah Luar Jawa Dan Madura.

Pasal 7 ayat (1) Kompilasi Hukum Islam.

Pasal 7 ayat (2) Kompilasi Hukum Islam.

Ibid.
} 
a. adanya perkawinan dalam rangka penyelesaian perceraian;

b. hilangnya akta nikah;

c. adanya keraguan tentang sah atau tidaknya salah satu syarat perkawinan,

d. adanya perkawinan yang terjadi sebelum berlakunya UU No. 1 Tahun 1974;

e. perkawinan yang dilakukan oleh mereka yang tidak mempunyai halangan perkawinan menurut UU No. 1 Tahun 1974.

Perkawinan yang dikatakan sah adalah perkawinan yang memenuhi ketentuan hukum agama bagi pasangan calon suami isteri yang akan melangsungkan perkawinan. Apabila perkawinan dilakukan menyimpang dari ketentuan hukum agama mengakibatkan perkawinan itu menjadi tidak sah. Supaya negara ikut bertanggung jawab dalam suatu perkawinan yang terjadi, maka perkawinan itu haruslah dilakukan pencatatan.

Pencatatan perkawinan bagi yang melangsungkan perkawinan menurut agama Islam dilakukan oleh Pegawai Pencatat. ${ }^{11}$ Pencatatan perkawinan bagi yang melangsungkan perkawinan selain beragama Islam dilakukan oleh Pegawai Pencatat Perkawinan pada Kantor Catatan Sipil. ${ }^{12}$ Perkawinan yang terjadi antara laki-laki dan perempuan hanyalah dapat dibuktikan dengan Akta Perkawinan yang diterbitkan oleh PPN pada KUA bagi yang beragama Islam dan Pegawai pada Kantor Catatan Sipil bagi orang yang non-muslim. Oleh karena itu, untuk menjamin hak-hak yang dimiliki oleh suami isteri dan seluruh anggota keluarga perkawinan yang terjadi haruslah sah menurut hukum agama dan kepercayaan yang dianut oleh pasangan suami isteri, juga haruslah sah menurut hukum negara. ${ }^{13}$
Hal ini sejalan dengan Putusan Kasasi Mahkamah Agung Reg. No. 1948/K/PID/1991 tentang Perkara Poligami Liar, Kawin di Bawah Tangan dan Tidak Dicatat pada Instansi yang Berwenang. Putusan ini mengemukakan bahwa perkawinan yang sah adalah perkawinan yang telah terpenuhinya ketentuan Pasal 2 ayat (1) dan ayat (2) UU No. 1 Tahun 1974 secara kumulatif. Suatu perkawinan yang dipandang sah dari segi agama, tetapi tidak sah menurut hukum negara menyebabkan perkawinan itu tidak ada perlindungan hukum dari negara selaku pihak yang mempunyai otoritas menegakkan kepastian hukum dalam melindungi hak-hak yang dimiliki oleh semua anggota keluarga. Bagir Manan berpandangan sebagai berikut mengenai status hukum perkawinan antar orang islam di Indonesia:

[...] dalam memahami status hukum perkawinan antar orang Islam di Indonesia, harus diketahui terlebih dahulu asas legalitas (legality atau beginsel) yang mendasari keberlakuan hukum perkawinan bagi orang Islam di Indonesia. Asas legalitas berarti setiap perbuatan (tindakan) hukum harus atau wajib mempunyai dasar hukum tertentu yang telah ada sebelum perbuatan hukum itu dilakukan. Selanjutnya, disampaikan bahwa suatu perbuatan hukum yang sah mengandung makna hubungan hukum dan akibat hukum menjadi sah pula. Konteks perkawinan, suatu perbuatan hukum perkawinan tersebut antara laki-laki dengan perempuan yang sah, menunjukkan pula bahwa pasangan suami isteri tersebut adalah sah. Demikian pula dengan akibat hukum lainnya, misalnya terjadinya hubungan kekeluargaan yang berakibat timbulnya larangan perkawinan dan juga terhadap harta kekayaan, maupun anak yang dilahirkan akibat perkawinan tersebut. ${ }^{14}$

\footnotetext{
Sebagaimana dimaksud dalam Undang-undang No. 32 Tahun 1954 tentang Pencatatan Nikah, Talak dan Rujuk. Lihat pula pada Pasal 2 ayat (1) Peraturan Pemerintah No. 9 Tahun 1975 tentang Pelaksanaan Undang-Undang Nomor 1 Tahun 1974 tentang Perkawinan.

12 Pasal 2 ayat (2) Peraturan Pemerintah No. 9 Tahun 1975 tentang Pelaksanaan Undang-undang Nomor 1 Tahun 1974 tentang Perkawinan.

13 Negara-negara Muslim, termasuk Pakistan, Indonesia, Afghanistan, Mesir, Nigeria, Sudan, Maroko dan Malaysia memiliki sistem hukum yang dipengaruhi oleh Syariah, dengan menyerahkan wewenang tertinggi konstitusi dan aturan hukum kepada Negara. Peran Syariah terbatas pada hal-hal pribadi dan keluarga. Lihat Syafaul Mudawam, "Syari'ah-Fiqih-Hukum Islam; Studi tentang Konstruksi Pemikiran Kontemporer", Jurnal Asy-Syir'ah, Vol. 46 No. II, Juli-Desember 2012, hlm. 414.

14 Bagir Manan, "Keabsahan dan Syarat-Syarat Perkawinan Antar Orang Islam Menurut UU No. 1 Tahun 1974", Makalah Seminar Nasional, dengan tema Hukum Keluarga dalam Sistem Hukum Nasional Antara Realitas dan Kepastian Hukum, diselenggarakan oleh Mahkamah Agung Republik Indonesia, Jakarta, 1 Agustus 2009.
} 
Lebih lanjut, Bagir Manan berpandangan bahwa perkawinan yang sah adalah perkawinan yang memenui ketentuan Pasal 2 ayat (1) UndangUndang Nomor 1 Tahun 1974, yaitu sah menurut agama, yang mempunyai akibat hukum yang sah pula. ${ }^{15}$ Pencatatan perkawinan sebagaimana ditentukan dalam Pasal 2 ayat (2) Undang-Undang Nomor 1 Tahun 1974 tidak menunjukkan kualifikasi sederajat yang bermakna sahnya perkawinan menurut agama adalah sama dengan pencatatan perkawinan, sehingga yang satu dapat menganulir yang lain.

Pemutusan hubungan perkawinan juga telah mendapat pengaturannya, baik dalam undangundang maupun dalam Kompilasi Hukum Islam. ${ }^{16}$ Berdasarkan peraturan tersebut, perkawinan dapat putus karena: ${ }^{17}$
a. kematian;
b. perceraian, dan
c. atas Putusan Pengadilan.

Putusnya perkawinan yang disebabkan karena perceraian dapat terjadi karena talak atau berdasarkan gugatan perceraian. ${ }^{18}$ Perceraian hanya dapat dilakukan di depan sidang pengadilan setelah hakim berusaha dan tidak berhasil mendamaikan kedua belah pihak. ${ }^{19}$ Perceraian hanya dapat dilakukan di depan sidang Pengadilan Agama setelah Pengadilan Agama tersebut berusaha dan tidak berhasil mendamaikan kedua belah pihak. ${ }^{20}$ Perceraian tersebut terjadi atau terhitung pada saat perceraian itu dinyatakan di depan sidang pengadilan. $^{21}$

Perkembangan perkawinan masa kini, apabila pengaturan hukum yang berhubungan dengan keluarga masih bersifat fakultatif, maka dipandang sulit untuk menegakkan tujuan hukum yang berfungsi untuk melindungi hak-hak yang dimiliki oleh setiap orang dalam suatu hubungan keluarga. Selain itu, akan sangat sulit untuk dapat mencapai tujuan hukum yang memenuhi rasa keadilan, kemanfaatan, dan kepastian hukum. Melihat fenomena persoalan keluarga pada masa kini (baik dalam hal perkawinan, perceraian, dan kewarisan), maka salah satu aspek hukum yang perlu mendapat perhatian yang serius yakni kehadiran Hukum Keluarga. Hukum keluarga memiliki peranan sangat krusial dalam mengatur masalah-masalah mulai dari pembentukan sebuah keluarga hingga memberikan jaminan atas terpenuhinya hak-hak yang dimiliki oleh masing-masing anggota keluarga.

Menurut Soediman Kartohadiprodjo, hukum keluarga adalah kesemuanya kaedah-kaedah hukum yang menentukan syarat-syarat dan caranya mengadakan hubungan abadi serta seluruh akibatnya, ${ }^{22}$ sedangkan menurut Wahbah Zuhaili menyatakan bahwa hukum keluarga (ahkam al-ahwal al-syakhsiyyah), adalah hukum yang mengatur hubungan keluarga sejak dimasa-masa awal pembentukannya hingga dimasa berakhirnya, berupa nikah, talak, nasab, nafkah, dan kewarisan. ${ }^{23}$ Mustafa Ahmad Zarqa menjelaskan tiga macam hukum keluarga, yaitu:

a. Perkawinan (munakahat) dan hal-hal yang bertalian dengannya;

b. Perwalian dan wasiat (al walayat wal washiyah);

c. Kewarisan (al-mawarits). ${ }^{24}$

Pada dasarnya, pengaturan hukum keluarga harus tegas, baik yang berkaitan dengan aspek perkawinan, maupun yang berkaitan dengan aspek perceraian, nafkah dan warisan.Adanya pelanggaranpelanggaran terhadap kewajiban pemenuhan hak,

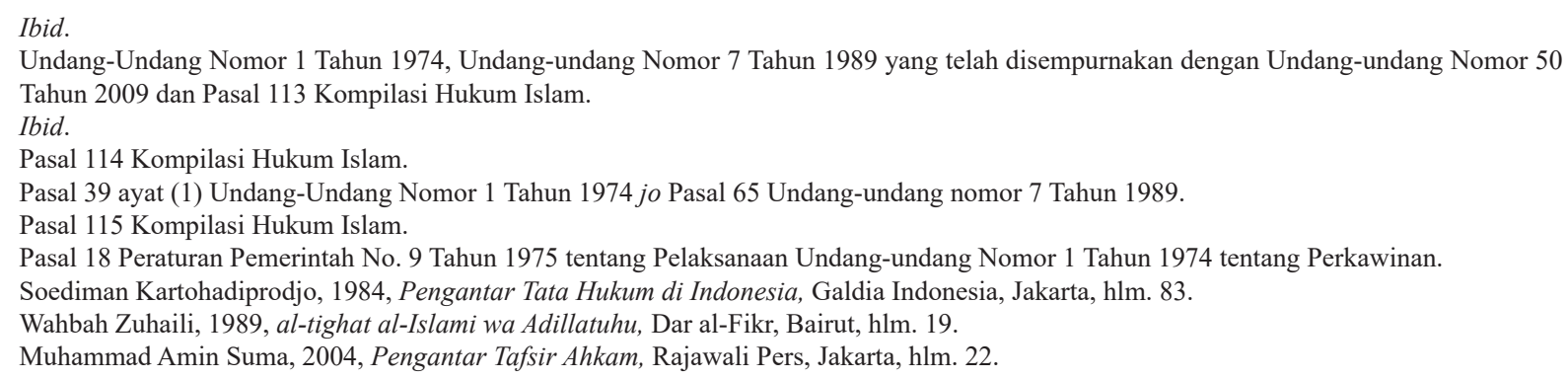


misalnya yang terjadi dalam perkawinan yang tidak tercatat atau perceraian yang tidak tercatat, dan menimbulkan penderitaan bagi pihak korban, maka kondisi ini ditengarai mengandung unsur pelanggaran maupun kejahatan dalam hubungan keluarga yang terhadapnya harus mendapatkan sanksi yang tegas. Oleh karena itu, menghadirkan hukum keluarga yang mampu mengangkat harkat dan martabat dalam bidang perkawinan dan perceraian, serta menjamin kepastian hukum dalam rangka melindungi hak-hak semua anggota keluarga dianggap perlu dilakukan. Penelitian ini dilakukan untuk mendapatkan jawaban atas rumusan masalah yakni: (1) Bagaimanakah kkondisi faktual hukum keluarga di Aceh?; (2) Bagaimana urgensi kehadiran hukum keluarga di Aceh?

\section{B. Metode Penelitian}

Penelitian ini merupakan penelitian kualitatif dengan mengaplikasikan metode deskriptif-analisis dan pendekatan yuridis normatif serta yuridis empiris. Penelitian ini menggunakan dua metode pengumpulan data, pengumpulan data primer dan data sekunder. Pengumpulan data primer (primary sources) dilakukan dengan teknik wawancara mendalam (in-depth interviews) dan Focus Group Discussion (FGD) serta observasi.

Analisis yang dipergunakan dalam penelitian adalah analisis kualitatif secara yuridis normatif dan yuridis empiris berdasarkan konsep-konsep yang diperoleh melalui studi dokumen dan wawancara. Berdasarkan analisis tersebut diharapkan dapat diperoleh gambaran menyeluruh mengenai kaidahkaidah yang berkaitan dengan permasalahan.

Penelitian ini menentukan 6 (enam) lokasi penelitian yang ada di Provinsi Aceh. Keenam provinsi tersebut adalah Kabupaten Pidie, Kabupaten Aceh Barat, Kabupaten Bener Meriah, Kabupaten Aceh Utara, Kota Langsa dan Kabupaten Bireuen. Pada tahun pertama telah melakukan wawancara dengan para hakim Mahkamah Syar'iyah pada lokasi penelitian serta para pihak (suami dan isteri berperkara) dan Tetua Adat, aparatur pada Majelis Adat Aceh (MAA) pada masing-masing kabupaten/ kota maupun masyarakat umum turut diwawancarai.

Pengumpulan data sekunder (secondary sources) dilakukan melalui penelusuran bahan-bahan tertulis seperti peraturan perundang-undangan, Putusan Mahkamah Syar'iyah dengan menganalisis secara mendalam pertimbangan-pertimbangan hukum dari Majelis Hakim dalam memutuskan perkara perceraian, khususnya atas perkara perceraian yang telah jatuh di luar Mahkamah Syar'iyah. Selain analisis terhadap Putusan Mahkamah Syar'iyah, telaah atas buku-buku, majalah, buletin, surat-kabar, dan bahan tertulis lainnya yang tidak diterbitkan juga akan menjadi bagian dari analisis penelitian ini. Pengumpulan data sekunder (secondary sources) dilakukan melalui penelusuran bahan-bahan tertulis seperti artikel dalam jurnal, buku-buku, majalah, buletin, surat-kabar dan bahan tertulis lainnya yang tidak diterbitkan.

Responden ditentukan secara purposive sampling. Responden yang diambil dari masingmasing kabupaten atau kota tersebut merupakan masyarakat yang pernah melakukan perceraian di luar Mahkamah Syar'iyah maupun yang melaksanakan perceraian melalui Mahkamah Syar'iyah.

\section{Hasil Penelitian dan Pembahasan 1. Fenomena Permasalahan Hukum Keluarga di Aceh}

Pembentukan hukum keluarga tidak dapat dipisahkan dari peristiwa perkawinan karena perkawinan merupakan bagian yang tidak terpisahkan dari hakikat hidup manusia untuk membentuk sebuah keluarga yang merupakan fundamen dasar dalam bangunan sebuah masyarakat. Bagi penganut agama Islam, proses pelaksanaan perkawinan tidak dapat dipisahkan dari ketentuan yang telah diatur dalam norma-norma agama Islam itu sendiri, demikian juga sebaliknya bagi agama non muslim harus mengikuti ketentuan agama dan kepercayaannya..$^{25}$

25 Pasal 2 Ayat (1) UU No. 1 Tahun 1974 dan Pasal 4 UU No. 7 Tahun 1989. 
Konteks NKRI, tidak boleh berlaku hukum perkawinan yang bertentangan dengan kaedahkaedah agama. ${ }^{26}$ Hukum perkawinan tidak boleh bertentangan dengan kaedah-kaedah Islam bagi orang Islam, atau hukum perkawinan tidak boleh bertentangan dengan kaedah-kaedah Nasrani bagi umat Nasrani, atau hukum perkawinan tidak boleh bertentangan dengan kaedah-kaedah Hindu bagi Umat Hindu, atau hukum perkawinan tidak boleh bertentangan dengan kesusilaan Agama Budha bagi umat Budha. Oleh karena itu, Negara Republik Indonesia wajib menjalankan syariat atau hukum perkawinan Islam bagi orang Islam, hukum perkawinan Nasrani bagi orang Nasrani, hukum perkawinan Hindu Bagi orang Hindu, dan hukum perkawinan Budha bagi orang Budha. ${ }^{27}$

Menurut Undang-undang, keabsahan perkawinan tidak hanya dilihat dari sahnya perkawinan menurut agama dan kepercayaannya, tetapi perlu juga adanya kepastian hukum dan jaminan dari institusi negara yang mempunyai otoritas untuk mendapatkan perlindungan bagi hakhak yang timbul dari perkawinan tersebut. Oleh karena itu, tidak kalah pentingnya setiap perkawinan harus dicatat menurut peraturan perundangundangan yang berlaku sebagaimana dimaksud dalam ayat (2). Pencatatan tiap-tiap perkawinan adalah sama halnya dengan pencatatan peristiwaperistiwa penting dalam kehidupan seseorang, misalnya kelahiran, kematian yang dinyatakan dalam surat-surat keterangan, suatu akta resmi yang juga dimuat dalam daftar pencatatan. ${ }^{28}$

Setiap perkawinan harus dilangsungkan di hadapan dan di bawah pengawasan Pegawai
Pencatat Nikah. ${ }^{29}$ Nikah yang dilakukan menurut agama Islam diawasi oleh Pegawai Pencatat Nikah yang diangkat oleh Menteri Agama atau oleh Pegawai yang ditunjuk. ${ }^{30}$ Pengawasan dan penerimaan pemberitahuan tentang talak dan rujuk hanya dapat dilakukan oleh pegawai yang diangkat oleh Menteri Agama atau oleh pegawai yang ditunjuk olehnya. ${ }^{31}$ Pegawai Pencatat Nikah membuat catatan tentang pernikahan yang dilakukan di bawah pengawasannya dan tentang talak dan rujuk yang diberitahukan kepadanya. Catatan dimasukkan di dalam buku pendaftaran masing-masing yang sengaja dilakukan untuk hal itu, dan contohnya masing-masing ditetapkan oleh Menteri Agama. ${ }^{32}$ Perkawinan yang dilakukan di luar pengawasan Pegawai Pencatat Nikah tidak mempunyai kekuatan hukum. ${ }^{33}$ Dengan demikian, setiap perkawinan haruslah dilakukan di hadapan Pegawai Pencatat Nikah yang diangkat oleh Menteri Agama. Pengawasan perkawinan tidak dibenarkan apabila dilakukan di luar pengawasan Pegawai Pencatat Nikah yang telah diangkat oleh Menteri Agama atau yang ditunjuknya.

Praktek perkawinan dalam masyarakat Aceh masih dilakukan tanpa sepengetahuan dan pengawasan Pegawai Pencatat Perkawinan yang diangkat oleh Menteri Agama. Perkawinan tersebut dilakukan secara di bawah tangan atau disebut juga kawin siri yang dilakukan oleh kadhi-kadhi yang tidak berwenang. Bentuk perkawinan semacam ini telah mengangkangi ketentuan-ketentuan yang diatur oleh Hukum Perkawinan Nasional, khususnya yang berkaitan dengan pencatatan perkawinan. Perkawinan yang demikian tidak diakui oleh istitusi negara, meskipun sudah dipandang sah menurut

26 Sebagai perbandingan, hukum keluarga Islam dalam perspektif HAM universal atau Universal Declaration Human Rights (UDHR) dan HAM Islam atau Universal Islamic Declaration Human Rights (UIDHR). Dalam UDHR (HAM Universal/Barat) perkawinan dibolehkan bagi pasangan suami (calon mempelai) tanpa pertimbangan agama sama sekali (pasal 2), sedangkan di dalam UIDHR (HAM Islam) terdapat indikasi kuat (pasal 19 ayat [1a]) bahwa perbedaan agama terlarang dalam pernikahan. Lihat dalam Muhammad Faisal Hamdani, 2016, "Hukum Keluarga Islam Dalam Perspektif HAM Universal (UDHR) dan HAM Islam (UIDHR)", Jurnal Ahkam, Vol. XVI, No. 1, Januari 2016, hlm. 21

27 Neng Djubaidah, 2010, Pencatatan Perkawinan dan Perkawinan Tidak Tercatat Menurut Hukum Tertulis di Indonesia dan Hukum Islam, Sinar Grafika, Jakarta, hlm. 213

28 Lihat, Penjelasan umum angka 4 huruf (b) Undang-Undang Nomor 1 Tahun 1974 tentang Perkawinan (Lembaran Negara Republik Indonesia Tahun 1974 Nomor 1, Tambahan Lembaran Negara Republik Indonesia Nomor 3019).

Pasal 6 Ayat (1) Kompilasi Hukum Islam.

Pasal 1 Ayat (1) Undang-Undang nomor 22 Tahun 1946 tentang Pencatatan Nikah, Talak dan Rujuk.

Pasal 1 Ayat (2) Undang-Undang nomor 22 Tahun 1946 tentang Pencatatan Nikah, Talak dan Rujuk.

Pasal 2 Ayat (1) Undang-Undang nomor 22 Tahun 1946 tentang Pencatatan Nikah, Talak dan Rujuk.

Pasal 6 Ayat (2) Kompilasi Hukum Islam. 
agama. Akibat dari perkawinan di bawah tangan yang tidak diakui oleh institusi negara menjadi masalah besar dalam kehidupan keluarga untuk masa-masa selanjutnya, terutama menyangkut dengan perlindungan terhadap hak-hak yang harus didapat oleh semua anggota keluarga, jika terjadi suatu masalah dalam keluarga tersebut.

Menurut Neng Djubaedah, istilah "tidak dicatat" tidak sama dengan istilah "tidak dicatatkan". ${ }^{34}$ Kedua istilah tersebut mengandung makna berbeda. Pada istilah "perkawinan tidak dicatat" bermakna bahwa perkawinan itu tidak mengan- dung unsur "dengan sengaja" yang mengiringi itikad atau niat seseorang untuk tidak mencatatkan perkawinannya. Adapun istilah "tidak dicatatkan" terkandung itikad atau niat buruk dari suami khususnya yang bermaksud perkawinannya memang dengan sengaja "tidak dicatatkan".

Kondisi ini kiranya dapat ditunjukkan dengan data yang diberikan oleh Badilag Mahkamah Agung Republik Indonesia terkait dengan laporan jumlah perkara yang diterima dan diputus pada Mahkamah Syar'iyah se Wilayah Aceh, khususnya terkait dengan perkara itsbat nikah ${ }^{35}$, sebagai berikut:

Tabel 1.

Perkara Isbath Nikah yang Diterima dan Diputus pada Mahkamah Syar'iyah Se-Wilayah Aceh Tahun 2012-2015

\begin{tabular}{|c|c|c|c|c|c|c|c|c|c|}
\hline \multirow[b]{2}{*}{ No } & \multirow[b]{2}{*}{$\begin{array}{c}\text { Mahkamah } \\
\text { Syar'iyah }\end{array}$} & \multicolumn{2}{|c|}{2012} & \multicolumn{2}{|c|}{2013} & \multicolumn{2}{|c|}{2014} & \multicolumn{2}{|c|}{$2015 * *$} \\
\hline & & $\begin{array}{l}\text { Perkara } \\
\text { Diterima }\end{array}$ & $\begin{array}{l}\text { Perkara } \\
\text { Diputus }\end{array}$ & $\begin{array}{c}\text { Perkara } \\
\text { Diterima }\end{array}$ & $\begin{array}{l}\text { Perkara } \\
\text { Diputus }\end{array}$ & $\begin{array}{l}\text { Perkara } \\
\text { Diterima }\end{array}$ & $\begin{array}{l}\text { Perkara } \\
\text { Diputus }\end{array}$ & $\begin{array}{l}\text { Perkara } \\
\text { Diterima }\end{array}$ & $\begin{array}{l}\text { Perkara } \\
\text { Diputus }\end{array}$ \\
\hline 1 & 2 & 3 & 4 & 5 & 6 & 7 & 8 & 9 & 10 \\
\hline 1 & Banda Aceh & 35 & 33 & 60 & 58 & 34 & 28 & 29 & \\
\hline 2 & Sigli & 157 & 139 & 131 & 127 & 104 & 86 & 132 & \\
\hline 3 & Takengon & 93 & 82 & 273 & 241 & 351 & 332 & 261 & \\
\hline 4 & Langsa & 4 & 4 & 20 & 15 & 10 & 4 & 15 & \\
\hline 5 & Lhokseumawe & 11 & 9 & 15 & 10 & 17 & 8 & 15 & \\
\hline 6 & Meulaboh & 39 & 40 & 29 & 27 & 28 & 30 & 1701 & \\
\hline 7 & Kutacane & 44 & 29 & 184 & 173 & 111 & 100 & 99 & \\
\hline 8 & Tapaktuan & 29 & 24 & 27 & 26 & 85 & 174 & 205 & \\
\hline 9 & Bireun & 69 & 64 & 47 & 45 & 29 & 28 & 37 & \\
\hline 10 & Jantho & 40 & 35 & 42 & 37 & 28 & 26 & 25 & \\
\hline 11 & Lhoksukon & 32 & 33 & 33 & 29 & 61 & 53 & 69 & \\
\hline 12 & Sabang & 2 & 2 & 3 & 1 & 2 & 3 & 1 & \\
\hline 13 & Mereudu & 105 & 96 & 50 & 38 & 42 & 51 & 48 & \\
\hline 14 & Idi & 8 & 10 & 8 & 7 & 11 & 9 & 60 & \\
\hline 15 & Kualasimpang & 5 & 5 & 3 & 2 & 8 & 8 & 1 & \\
\hline 16 & Blangkejeren & 66 & 70 & 115 & 110 & 295 & 282 & 104 & \\
\hline 17 & Calang & 37 & 36 & 56 & 56 & 61 & 56 & 121 & \\
\hline 18 & Singkil & - & - & 4 & 6 & 5 & 2 & 6 & \\
\hline 19 & Sinabang & 2 & 2 & 19 & 13 & 21 & 18 & 9 & \\
\hline 20 & $\begin{array}{l}\text { Simpang Tiga } \\
\text { Redelong }\end{array}$ & 16 & 15 & 20 & 19 & 20 & 13 & 11 & \\
\hline & Jumlah & 794 & 728 & 1.139 & 1.040 & 1.323 & 1.311 & 2.949 & \\
\hline
\end{tabular}

Sumber : Data olahan Penulis yang berasal dari rekapitulasi jumlah perkara seluruh Mahkamah Syar'iyah di Aceh, Tahun 2012 s.d 2015, dan data tersedia sampai dengan Agustus 2015.

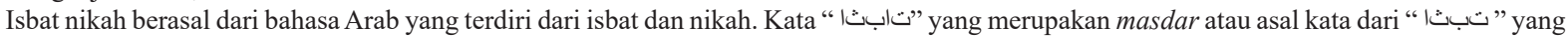
memiliki arti "menetapkan", dan kata "حاكن" yang berasal dari kata "حكن "yang memiliki arti “saling menikah", dengan demikian kata "isbat nikah" memiliki arti yaitu "penetapan pernikahan. Lebih lanjut lihat Ahmad Warsono Munawwir, 1997, Al-Munawir: Kamus Arab-Indonesia, Pustaka Progressif, Surabaya, hlm. 145. 
Tabel di atas, menjadi salah satu sample dari berbagai permasalahan di bidang hukum keluarga yang terjadi di Aceh. Fenomena perkawinan yang tidak dicatatkan di Aceh, kiranya terlihat jelas melalui tabel rekapitulasi di atas. Para pihak suami dan isteri telah memanfaatkan fasilitas yang disediakan oleh negara untuk mencatatkan perkawinannya melalui itsbat nikah. ${ }^{36}$ Data yang ditampilkan telah menunjukkan, misalnya saja pada kota Sigli, Takengon, dan Meureudu bahwa jumlah pengajuan perkara itsbat nikah dari tahun ke tahun menunjukkan angka yang cukup tinggi. Realitas yang melatarbelakangi terhadap pengajuan perkara ini kiranya perlu ditindaklanjuti dalam berbagai riset mendalam, baik dari aspek hukum maupun riset-riset antropologi dan sosiologi.

Mengkaji atas fenomena praktik perkawinan maupun perceraian yang dilakukan oleh masyarakat Aceh disandingkan dengan pengaturan melalui UU No. 1 Tahun 1974 dan KHI, maka pengaturan tersebut khususnya berkaitan dengan masalah hukum keluarga dianggap belum mampu mengantisipasi angka perkawinan tak tercatat yang dilakukan oleh masyarakat pada kadhi-kadhi yang tidak berwenang. Disatu sisi, perkawinan yang dilakukan oleh kadhi-kadhi yang tidak berwenang sudah dipandang sah oleh masyarakat secara agama, sehingga pencatatan perkawinan tidaklah begitu penting. Perkawinan tersebut juga dianggap membawa akibat hukumnya bagi suami isteri beserta semua anggota keluarga dari keturunannya, meskipun perkawinan tidak dicatat oleh Pegawai Pencatat Perkawinan pada KUA dalam wilayah tempat dilangsungkannya perkawinan.

Adanya pandangan berbeda antara masyarakat, tetua adat, ulama maupun para pakar dengan para hakim di Mahkamah Syar'iyah terkait dengan keabsahan perkawinan dan permasalahanpermasalahan atas perkawinan yang tidak tercatat, membawa akibat secara langsung bagi kehidupan keluarga tersebut, yaitu tidak adanya akta nikah. Tidak adanya akta nikah dalam regulasi kependudukan Negara Republik Indonesia akan mengakibatkan secara langsung tidak dapat dilakukannya pengurusan atas akta kelahiran anak. Lebih lanjut, akibat yang mungkin muncul dari ketiadaan akta tersebut adalah hambatan bagi anak untuk mendapatkan jaminan pemenuhan hakhaknya, ${ }^{37}$ misalnya untuk mendaftarkan sekolah maupun fasilitas layanan kesehatan. Lebih lanjut, dalam hal timbulnya konflik dalam keberlangsungan keluarga yang mengakibatkan putusnya hubungan perkawinan, maka para pihak tidak akan dapat mengajukan penyelesaian perkaranya baik atas putusnya perkawinan dimaksud maupun sengketasengketa yang mungkin timbul di bidang harta kekayaan ke hadapan sidang pengadilan Mahkamah Syar'iyah dikarenakan ketiadaan Akta Nikah.

Perbuatan yang halal tetapi dibenci Allah adalah perceraian. Namun, tidaklah semua perkawinan dapat bertahan selama-lamanya, banyak perkawinan yang putus di tengah jalan sebagai akibat dari konflik rumah tangga yang terus menerus yang menyebabkan tujuan perkawinan tidak tercapai dalam membentuk keluarga bahagia dan kekal yang berujung pada perceraian. Bahkan, perceraian di Aceh didominasi oleh gugatan isteri (fasakh). ${ }^{38}$ Berdasarkan data yang diperoleh dari Mahkamah Syar'iyah Aceh pada Tahun 2014 terdapat 4.801 orang yang mendaftar diri pada 20 Mahkamah Syar'iyah yang ada di Aceh. Permohonan yang diterima Mahkamah Syar'iyah ini terdiri atas permohonan suami (cerai talak) sebanyak 1.344 permohonan, sementara permohonan isteri atau

\footnotetext{
36 Pelaksanaan isbat nikah tidak berbeda dengan pengadilan lainnya, misalnya Pengadilan Agama Pandeglang, yaitu sesuai dengan prosedur yang diatur dalam peraturan perundang-undangan yang berlaku. Berdasarkan data, tampak bahwa isbat nikah yang terjadi di Pengadilan Agama Pandeglang setiap tahunnya mengalami peningkatan. Pada 2012 jumlah perkara isbat nikah berjumlah 41 perkara dan pada 2013 meningkat menjadi 68 perkara, kemudian di tahun 2014 menjadi 135 perkara. Sedangkan pada 2015 tercatat 68 perkara karena belum sampai akhir tahun. Isbat nikah yang ditetapkan oleh Pengadilan Agama Pandeglang adalah perkawinan yang sudah memenuhi rukun dan syarat nikah namun tidak dicatatkan karena tidak mampu sehingga pengajuan isbat nikahnya juga bebas biaya. Lihat, Ahmad Sanusi, "Pelaksanaan Isbat Nikah di Pengadilan Agama Pandeglang”, Jurnal Ahkam, Vol. XVI, No. 1, Januari 2016, hlm. 113.

37 Karena salah satu syarat yang harus dipenuhi adalah adanya Akta Kelahiran.

38 Serambi Indonesia, "Banyak Isteri Minta Cerai", http://aceh.tribunnews.com/2016/02/14/banyak-istri-minta-cerai, diakses 18 Agustus 2016.
} 
cerai gugat (fasakh) jauh lebih tinggi yakni 3.457 permohonan. Jumlah kasus yang didaftarkan dan kasus yang diputuskan bercerai oleh masingmasing Mahkamah Syar'iyah Kabupaten atau Kota se Aceh berjumlah 4.124 kasus. Putusan ini terdiri atas 1.146 cerai talak dan 2.978 gugat cerai. Pada tahun 2015 jumlahnya kian meningkat. Mahkamah Syar'iyah se Aceh telah menerima 5.300 permohonan perceraian. Permohonan perceraian ini didominasi oleh permintaan isteri, yang mencapai 3.850 permohonan, sedangkan permintaan yang dilakukan oleh suami hanya 1.450 permohonan. Berdasarkan jumlah tersebut, Mahkamah Syar'iyah di Kabupaten/Kota telah memutuskan 4.621 perceraian yang terdiri dari 1.212 cerai talak dan 3.409 fasakh.

Terkait dengan pengaturan hukum yang ada dalam UU Perkawinan, Tgk. H. Hanafiah Hamzah berpendapat sebagai berikut:

Keberadaan UU No. 1 Tahun 1974 telah menekan angka perceraian yang tercatat, bukan perceraiannya sendiri dan Bahkan perbuatan cerainya jauh lebih banyak dari angka yang dicatat oleh statistik Mahkamah Syar'iyah. UU No. 1 Tahun 1974 adalah undang-undang yang menganiaya perempuan. Hal ini disebabkan dengan adanya kondisi dimana suami isteri yang sudah bercerai di kampung, kemudian membawa perkaranya ke Mahkamah Syar'iyah dan ternyata berdamai setelah proses mediasi pengadilan, kemudian pulang ke rumah sama-sama padahal sudah jatuh talak sebelumnya, apakah talak 1 (satu) atau talak 2 (dua) dan kemudian tidak dianjurkan untuk ruju' atau menikah kembali. Bukan kah ini sama seperti zina terhormat, hanya karena punya buku nikah. ${ }^{39}$

Keberadaan Mahkamah Syar'iyah sebagai rujukan masyarakat dalam menyelesaikan konflik rumah tangga diakui oleh masyarakat. Hal ini dinyatakan oleh Abu Mustafa Paloh Gadeng, yaitu:
Mahkamah Syar'iyah harus menerima cerai (yang telah dilakukan oleh masyarakat di luar mahkamah) karena pada zaman Rasulullah SAW tidak ada yang di hadapan hakim. Hakim harus menerima, sebagai perbandingan harus ada saksi dan atau pengakuan tetapi tampaknya Mahkamah Syar'iyah mempersulit dan mahkamah harus diluruskan. ${ }^{40}$

Hal senada juga dinyatakan oleh Tengku Rasyidi sebagai berikut:

Secara syariat perceraian di luar pengadilan adalah sah hukumnya, karena suatu perceraian akan jatuh bila seorang suami telah menjatuhkan atau mengucapkan talak kepada isterinya, bila talak tersebut diucapkan sekali maka jatuhlah talak 1 (satu), dan bila diucapkan talak 3 (tiga) maka jatuhlah talak 3 (tiga). Sampai saat ini pihak Majelis Permusyawaratan Ulama (MPU) belum mengerti atas dasar apa Mahkamah Syar'iyah mendamaikan para pihak yang sudah menjatuhkan talak 3 (tiga) kepada istri. ${ }^{41}$

Problematika status atau kepastian hukum atas perbuatan cerai yang dilakukan oleh masyarakat di luar Mahkamah Syar'iyah, antara ketentuan hukum syari'at dengan hukum negara dipandang oleh pihak ulama sebagai sikap berlebihan dari negara. Bagi Abu Mustafa, hal ini menunjukkan bahwa negara hanya setengah hati memberikan kesempatan untuk Aceh melaksanakan syari'at Islam secara kaffah. ${ }^{42}$ Menurut beliau, banyak hal yang harusnya dapat diperbaiki dan bahkan keberadaan Mahkamah Syar'iyah harus diluruskan. ${ }^{43}$

Pada saat FGD yang penulis lakukan dengan ulama di MPU Bireuen, salah seorang ulama menyampaikan bahwa semua permasalahan yang muncul di masyarakat tampaknya menjadi masalah-masalah syari'at orang Islam yang tidak tertanggung di negeri syari'at. ${ }^{44}$ Lebih lanjut beliau

\footnotetext{
Wawancara dengan Tgk. H. Hanafiah Hamzah, Ketua Majelis Permusyawaratan Ulama Bireuen, tanggal 15 Juli 2014.

Wawancara dengan Abu Mustafa Paloh Gadeng, Ketua Majelis Permusyawaratan Ulama Aceh Utara, tanggal 28 Mei 2014.

Wawancara dengan Tengku Rasyidi, Ketua Majelis Permusyawaratan Ulama Pidie, tanggal 19 Mei 2014.

Wawancara dengan Abu Mustafa Paloh Gadeng, Ketua Majelis Permusyawaratan Ulama Aceh Utara, tanggal 28 Mei 2014.

Ibid.

Wawancara dengan Tgk. Heli Imran, Anggota Majelis Permusyawaratan Ulama Bireuen, tanggal 15 Juli 2014.
} 
juga menyatakan sebagai berikut:

Ada tarik menarik antara hukum syariat dengan hukum negara. Kondisi sebagaimana disampaikan oleh banyak pihak, adanya problematika kepastian hukum dan keadilan adalah cerminan dari pluralisme hukum yang lemah. Banyak pihak menginginkan pelaksanaan syari'at Islam dapat berjalan secara kaffah di Aceh dengan pemberian kewenangan yang lebih luas dalam menjalankan syari'at yang tidak hanya terbatas pada pelaksanaan hukum jinayah. ${ }^{45}$

Akibat hukum dari perceraian di bawah tangan meskipun secara agama dipandang sah, namun dianggap tidak sah menurut sistem hukum perkawinan nasional sehingga perceraian yang dilakukan tersebut dianggap tidak pernah terjadi. Dengan demikian, konsekuensinya jika seorang isteri yang telah diceraikan di bawah tangan menuntut pembayaran nafkah kepada suaminya, maka tidak dapat diproses karena perceraian yang dilakukannya di luar pengadilan. Demikian juga jika seorang isteri yang telah diceraikan di bawah tangan tidak dapat melakukan perkawinan dengan laki-laki lain melalui KUA. Hal ini sesuai dengan pendapat Zulkifli, yang menyampaikan adanya kondisi dalam hal mana banyak pihak yang bercerai kemudian datang ke KUA untuk meminta kartu kuning $^{46}$ untuk bercerai. ${ }^{47}$

Kondisi umum di dalam masyarakat saat ini, ketika perceraian terjadi di bawah tangan atau tidak dilangsungkan di hadapan Mahkamah Syar'iyah, maka para pihak akan melangsungkan pernikahan berikutnya dengan cara yang sama yaitu tidak mencatatkannya juga. Hal tersebut dikarenakan perceraian tidak melalui mahkamah, maka pernikahan berikutnya tidak mencatatkan pada KUA tanpa menunjukkan Akta Cerai sebagai salah satu persyaratan untuk melakukan pernikahan kembali. Kondisi ini tidak akan mampu dicapai oleh pasangan yang telah bercerai tanpa persidangan di Mahkamah Syar'iyah. Bagi aparatur negara, perceraian maupun perkawinan yang tidak dicatatkan ini sama-sama tidak mendapatkan pengakuan atau dipandang tidak pernah terjadi.

Menurut perundang-undangan perkawinan yang menjadi rujukan bagi hakim adalah ketentuan Pasal 39 ayat (1) UU No. 1 Tahun $1974,{ }^{48}$ Pasal 65 UU No. 7 Tahun $1989^{49}$ dan Pasal 115 KHI. ${ }^{50}$ Kandungan dari ketentuan beberapa pasal tersebut adalah perceraian hanya dapat dilakukan di depan sidang pengadilan. Perceraian itu terjadi terhitung pada saat perceraian itu dinyatakan di depan sidang pengadilan. ${ }^{51}$ Hal ini menunjukkan kalimat yang tegas, bahwa tidak ada perceraian di luar sidang pengadilan. Setiap orang yang ingin bercerai harus melalui proses sidang pengadilan. Hakim pengadilan-lah yang menentukan dapat tidaknya sepasang suami isteri bercerai dan hakimlah yang memberikan kepastian telah terjadi perceraian.

Persepsi ulama, tokoh adat, masyarakat dan para pakar jika disandingkan dengan pandangan hakim mahkamah saling bertentangan terhadap perkawinan yang terjadi di luar pengawasan Pegawai Pencatat Nikah, dan perceraian yang telah terjadi di luar Mahkamah Syar'iyah menurut hukum perkawinan nasional, maka hukum-hukum keluarga yang sudah ada dan berlaku secara nasional belum mampu menyelesakan berbagai persoalan perkawinan dan perceraian yang terjadi di tengahtengah masyarakat Aceh secara adil. Lebih lanjut, angka perceraian di luar mahkamah semakin tinggi yang berimbas pada tingginya angka perkawinan di bawah tangan.

\footnotetext{
Ibid.

Kartu kuning adalah istilah dalam masyarakat untuk (akta cerai) kepada KUA.

Wawancara dengan Zulkifli, Kepala Kantor Urusan Agama Kecamatan Senagan, Nagan Raya, tanggal 21 Agustus 2015.

Pasal 39 ayat (1), yaitu perceraian hanya dapat dilakukan di depan Sidang Pengadilan setelah Pengadilan yang bersangkutan berusaha dan tidak berhasil mendamaikan kedua belah pihak.

49 Pasal 65 UU No. 7 Tahun 1989 "perceraian hanya dapat dilakukan di depan sidang pengadilan setelah pengadilan yang bersangkutan berusaha dan tidak berhasil mendamaikan kedua belah pihak."

50 Pasal 115 KHI "Perceraian hanya dapat dilakukan di depan sidang Pengadilan Agama setelah Pengadilan Agama tersebut berusaha dan tidak berhasil mendamaikan kedua belah pihak."

51 Pasal 18 Peraturan Pemerintah No. 9 Tahun 1975 tentang Pelaksanaan Undang-undang Nomor 1 Tahun 1974 tentang Perkawinan.
} 
Selain itu, ketentuan hukum yang sudah ada semakin memperuncing dan menciptakan jurang pemisah yang tajam antara ulama, tokoh adat, dan masyarakat dengan hakim Mahkamah Syar'iyah dalam menghadapi masalah perkawinan dan perceraian, sehingga hak-hak isteri pasca perceraian dan hak-hak hadhanah anak, serta hakhak atas harta warisan jika ada diantara anggota keluarga yang meninggal dunia tidak terlindungi secara hukum. Dengan demikian hak-hak isteri dan anak-anaknya sering terzalimi sebagai akibat dari perceraian tersebut.

\section{Urgensi Kehadiran Hukum Keluarga di Aceh}

Memperhatikan berbagai fenomena dalam perkawinan dan perceraian yang terjadi dalam masyarakat, khususnya masyarakat Aceh, maka ketentuan hukum yang telah ada dan berlaku secara nasional belum mampu menyelesaikan berbagai persoalan perkawinan dan perceraian yang terjadi secara komprehensif dalam rangka memenuhi azas kemanfaatan dan keadilan, serta kepastian hukum sebagai tujuan dari ketentuan hukum itu sendiri. Padahal melalui perkawinan yang diatur oleh hukum akan memperjelas hubungan dan kedudukan suami isteri, memperjelas keturunan, memperjelas perwalian dan memperjelas pewarisan serta memperjelas hak dan kewajiban yang harus dilidungi oleh hukum, sehingga akan terbentuk keluarga sakinah. ${ }^{52}$

Hukum perkawinan nasional, sebagai ketentuan hukum yang dibuat untuk mengatur hubungan dan melindungi kepentingan keluarga haruslah diterima oleh semua komponen, baik komponen penguasa negara, maupun komponen ulama dan masyarakat, sehingga hukum itu dapat terlaksana dengan baik dalam rangka memberikan kepastian dan perlindungan hukum terhadap kepentingan anggota keluarga. Hukum yang mengatur hubungan dan kehidupan keluarga haruslah kemanfaatan, kepastian dan keadilan untuk menjaga keseimbangan terhadap kepentingan anggota keluarga.

Hukum keluarga yang sudah ada, khususnya ketentuan Pasal 39 ayat (1) UU No. 1 Tahun 1974, Pasal 65 UU No. 7 Tahun 1989 dan Pasal 115 KHI terjadi interprestasi yang sangat berbeda dan tajam antara ulama, tokoh adat, dan masyarakat disatu pihak dengan hakim sebagai pihak yang diberikan otoritas kewenangan untuk menegakkan hukum keluarga. Perbedaan tersebut akan mendapatkan hambatan dalam penegakannya. Hambatanhambatan yang ditemukan dalam menegakkan hukum perkawinan nasional adalah masih terjadinya perceraian di luar Mahkamah Syar'iyah dan terhadap perceraian tersebut adanya kesepahaman antara masyarakat dengan ulama, tokoh masyarakat dan pimpinan kampung bahwa perceraian dengan talak yang dilakukan oleh suami terhadap isteri di luar Mahkamah Syar'iyah sah hukumnya menurut Hukum Islam. ${ }^{53}$

Para ulama, tokoh adat dan masyarakat masih yakin dengan ketentuan hukum Fiqh Islam yang mengatur masalah perkawinan dalam melahirkan hubungan keluarga dan perceraian yang menyebabkan putusnya perkawinan. Menurut Alyasa Abubakar, bagi umat Islam aturan mengenai perceraian ini merupakan ganjalan yang relatif masih besar atau sekurang-kurangnya masih menjadi tanda tanya yang belum terjawab, karena dirasakan tidak sejalan dengan kesadaran hukum yang selama ini berkembang, yaitu aturan Fiqh. ${ }^{54}$

\footnotetext{
Sakinah dan/atau boleh jadi disebut "seutuhnya" atau "kebahagiaan hakiki" adalah perpaduan antara tiga unsur, yakni: (1) "kesenangan dan/ atau kesejahteraan", (2) "ketenteraman", dan (3) "keselamatan". "Kesenangan dan/atau kesejahteraan" dapat diraih dengan ter/memenuhi kebutuhan fisik-material. Sementara "Ketenteraman" dapat digapai dengan ter/memenuhi kebutuhan moril-spirituil. Adapun "keselamatan" dapat terpenuhi dengan mematuhi norma dan etika agama, termasuk norma dan etika sosial serta hukum alam. Kata keselamatan dapat pula diganti dengan mendapat ridha dan berkah dari Allah Swt. Karena itu, ungkapan lain untuk kebahagiaan hakiki adalah kesenangan dan ketenteraman yang diridhai dan diberkahi Allah Swt. Lihat, Khoiruddin Nasution, "Arah Pembangunan Hukum Keluarga Islam Indonesia: Pendekatan Integratif dan Interkonekstif dalam Membangun Keluarga Sakinah”, Jurnal Asy-Syir'ah, Vol. 46 No. I, Januari-Juni 2012, hlm. 100.

53 Jamaluddin, 2010, Hukum Perceraian (Dalam Pendekatan Empiris), Pustaka Bangsa Press, Medan, hlm. 42-43.

54 Alyasa Abubakar, "Ihwal Perceraian di Indonesia: Perkembangan Pemikiran Dari Undang-Undang Perkawinan sampai KHI (Bagian I)", Mimbar Hukum, No. 40 Tahun IX, 1998, hlm. 57.
} 
Aturan Fiqh mengizinkan perceraian atas dasar kerelaan kedua belah pihak, atau inisiatif suami atau juga inisiatif isteri secara sepihak, bahkan perceraian boleh dilakukan tanpa campur tangan lembaga peradilan. ${ }^{55}$ Perbedaan tersebut menyebabkan banyak terjadi pelanggaran terhadap ketentuan hukum keluarga (Hukum Perkawinan) oleh masyarakat. Selain itu, menunjukkan bahwa hukum keluarga tidak mampu memberikan perlindungan terhadap hak-hak yang dimiliki oleh pihak yang lemah dalam suatu hubungan keluarga.

Dalam kondisi inilah dibutuhkan kehadiran hukum keluarga yang memenuhi azas kemanfaatan, keadilan, dan kepastian hukum untuk menjamin hak-hak yang timbul akibat adanya hubungan hukum karena perkawinan. Hukum keluarga harus mampu membawa kemaslahatan dalam pelaksanaan atau dalam penegakannya. Hukum adalah untuk manusia, maka pelaksanaan hukum atau penegakan hukum harus memberi maslahat atau kegunaan bagi masyarakat. Jangan sampai justru karena hukumnya dilaksanakan atau ditegakkan timbul keresahan di dalam masyarakat. ${ }^{56}$ Hukum yang baik adalah hukum yang sesuai dengan hukum yang hidup dalam masyarakat. ${ }^{57}$ Kemudian hukum yang baik adalah juga hukum yang mampu memberi perlindungan terhadap hak-hak dari ketertindasan dari pihak lain yang dimiliki oleh setiap orang akibat dari adanya hubungan perkawinan. Hukum adalah pernyataan kesucian dan moralitas yang tinggi, baik dalam peraturan maupun dalam pelaksanaannya sebagaimana diajarkan dalam agama dan adat. Tidak perlu adanya pertentangan antara maksud untuk mengadakan pembaharuan hukum melalui perundang-undangan dan menyalurkan nilai-nilai atau aspirasi yang hidup dalam masyarakat..$^{58}$

Aceh yang telah diberikan keistimewaan untuk melaksanakan syariat Islam melalui Undang-undang Nomor 11 Tahun 2006 tentang Pemerintahan Aceh, ${ }^{59}$ maka sudah saatnya Aceh melahirkan Qanun Hukum Keluarga di Aceh yang sesuai dengan filosofi kehidupan masyarakat Aceh. Qanun yang akan lahir dapat menjunjung tinggi nilai-nilai ketuhanan, nilai-nilai kemanusiaan, nilai-nilai persatuan dan kesatuan, nilai-nilai permusyawaratan, dan nilai-nilai keadilan. Qanun Hukum keluarga yang dibuat harus mampu memberikan perlindungan dan kepastian hukum terhadap harkat dan martabat manusia dalam suatu perkawinan dan perceraian yang dilakukan.

Qanun hukum keluarga yang mengatur dalam bidang perkawinan, perceraian, perwalian, kekuasaan orang tua dan kewarisan tidaklah hanya bersifat mengatur saja (fakultatif), tetapi hukum keluarga haruslah memberi upaya paksa (imperatif), agar setiap orang dalam melakukan hubungan hukum melalui perkawinan, perceraian, perwalian dan pewarisan tidak mengabaikan hak-hak pihak lain atau menindaskan hak-hak orang lain. Hukum harus mampu mencegah dan memberikan solusi yang cepat dan tepat dalam berbagai pelanggaran dan kejahatan dalam setiap hubungan keluarga, karena pengingkaran terhadap hak-hak pihak lain dalam suatu hubungan keluarga yang menyebabkan pihak lain menderita dan tersiksa dapat dikatagorikan sebagai sebuah pelanggaran atau sebuah kejahatan yang dapat diancam dengan sanksi yang tegas. ${ }^{60}$

Menurut Mardani, keberadaan Hukum

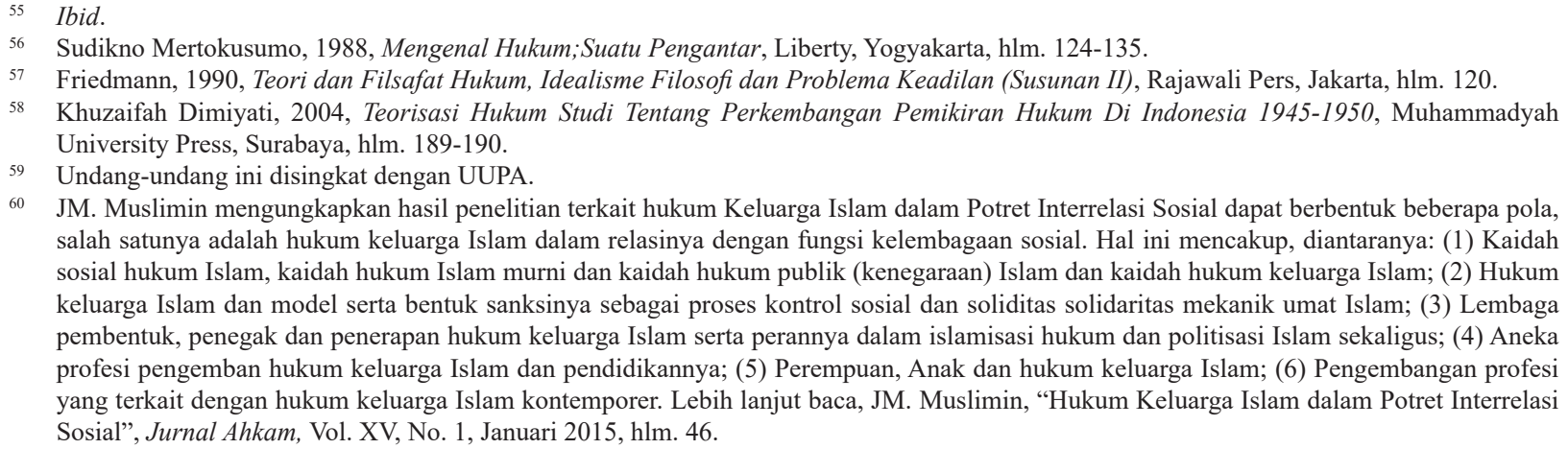

60 JM. Muslimin mengungkapkan hasil penelitian terkait hukum Keluarga Islam dalam Potret Interrelasi Sosial dapat berbentuk beberapa pola, salah satunya adalah hukum keluarga Islam dalam relasinya dengan fungsi kelembagaan sosial. Hal ini mencakup, diantaranya: (1) Kaidah sosial hukum Islam, kaidah hukum Islam murni dan kaidah hukum publik (kenegaraan) Islam dan kaidah hukum keluarga Islam; (2) Hukum keluarga Islam dan model serta bentuk sanksinya sebagai proses kontrol sosial dan soliditas solidaritas mekanik umat Islam; (3) Lembaga pembentuk, penegak dan penerapan hukum keluarga Islam serta perannya dalam islamisasi hukum dan politisasi Islam sekaligus; (4) Aneka profesi pengemban hukum keluarga Islam dan pendidikannya; (5) Perempuan, Anak dan hukum keluarga Islam; (6) Pengembangan profesi yang terkait dengan hukum keluarga Islam kontemporer. Lebih lanjut baca, JM. Muslimin, "Hukum Keluarga Islam dalam Potret Interrelasi Sosial", Jurnal Ahkam, Vol. XV, No. 1, Januari 2015, hlm. 46. 
Keluarga mempunyai tingkat urgensitas yang tinggi, karena sesuai dengan fitrahnya, manusia tidak dapat hidup menyendiri dalam arti ia memiliki sifat ketergantungan dan saling membutuhkan, demikian halnya antara pria dan wanita. ${ }^{61}$ Demi menjaga hubungan antara pria dan wanita dapat hidup rukun, maka Islam mengatur melalui ketentuan-ketentuan hukum tata hidup berkeluarga atau rumah tangga melalui pernikahan yang sah. ${ }^{62}$

Pengaturan secara khusus melalui qanun menjadi sebuah hukum keluarga di Aceh sangat memungkinkan terjadi. Hal ini sesuai dengan grand design penerapan syariat Islam yang kaffah di Aceh yang mengatur berbagai aspek, yaitu akidah, Syar'iyah dan akhlak. Hal tersebut sebagaimana dinyatakan oleh Syahrizal Abbas sebagai berikut “[...] perkembangan penerapan Syar'iyah di Aceh, salah satunya dimulai dengan sedang dirancangnya Grand Design penerapan syariat Islam dengan baik. Indikator baik adalah pertama, amanah yang diberikan melalui Undang-Undang Nomor 11 Tahun 2006 tentang Pemerintah Aceh." ${ }^{\text {63 }}$

Lebih lanjut, Syahrizal Abbas menjelaskan penerapan syariat Islam luas sekali, yaitu dari barat sampai timur (seluruh totalitas ajaran Islam itulah sunnah) yang akan dilakukan secara kaffah, yaitu mencakup segala bidang. ${ }^{64}$ Pengaturan di berbagai bidang tersebut dengan memadukan dua dimensi yaitu normatif formal dengan nomatif spiritual (fiqh). Oleh karena itu, pengaturan akan mencakup bidang aqidah, syar'iyah dan akhlak ini kemudian dikenal dengan "taqnin" yang akan dikodifikasikan dalam qanun pokok-pokok syariat Islam. Di dalam qanun pokok syariat Islam, ada bidang Syar'iyah di dalamnya ada bidang muamalah, termasuk di dalamnya qanun keluarga yang mampu mengatur hak dan kewajiban perempuan, hak-hak pasca perceraian, dan lain-lain. Perlu diketahui bahwa semangat reaktualisasi hukum Islam dalam bidang hukum keluarga umumnya adalah melindungi dan memperbaiki kedudukan wanita serta melindungi anak-anak. ${ }^{65}$

Adanya pengaturan-pengaturan terkait dalam bidang muamalah, khususnya qanun Aceh tentang hukum keluarga, serta mencakup pengaturan atas kejahatan dan pelanggaran, maka upaya pencegahan terjadinya perceraian di luar Mahkamah Syar'iyah dapat terlaksana, sehingga hak-hak perempuan dan anak-anak khususnya mantan isteri dapat terlindungi. Pengaturan secara khusus melalui qanun dapat saja dilakukan yang penting adalah aturan yang dibuat tersebut tidak saling bersinggungan atau kontra.

\section{Kesimpulan}

1. Fenomena permasalahan hukum keluarga di Aceh mempunyai berbagai pandangan yang berbeda antara masyarakat, tetua adat, ulama maupun para pakar dengan para hakim di Mahkamah Syar'iyah terkait dengan keabsahan perkawinan dan permasalahan-permasalahan atas perkawinan yang tidak tercatat. Namun, dalam regulasi kependudukan negara membawa akibat secara langsung atas kehidupan keluarga. Tidak adanya akta nikah dari pasangan suami isteri akan mengakibatkan secara langsung tidak dapat dilakukannya pengurusan atas akta kelahiran anak. Selanjutnya, timbulnya konflik dalam keluarga yang mengakibatkan putusnya hubungan perkawinan.

2. Urgensi kehadiran hukum keluarga di Aceh karena aturan yang ada belum mampu memberikan perlindungan terhadap hak-hak yang dimiliki oleh pihak yang lemah dalam

\footnotetext{
Mardani, 2016, Hukum Keluarga Islam di Indonesia, Prenada Media Group, Jakarta, hlm. 5-6.

Ibid.

Wawancara Syahrizal Abbas, Kepala Dinas Syariat Islam Provinsi Aceh, tanggal 20 Januari 2015. Lebih lanjut mengenai syariat Islam yang dilaksanakan di Aceh terdapat pada Pasal 125 UUPA sebagai berikut: (1) Syari'at Islam yang dilaksanakan di Aceh meliputi aqidah, syar'iyah dan akhlak. (2) Syari'at Islam sebagaimana dimaksud pada ayat (1) meliputi ibadah, ahwal alsyakhshiyah (hukum keluarga), muamalah (hukum perdata), jinayah (hukum pidana), qadha' (peradilan), tarbiyah (pendidikan), dakwah, syiar, dan pembelaan Islam.

65 Muhibbuthabry, "Poligami dan Sanksinya Menurut Perundang-undangan Negara-negara Modern, Jurnal Ahkam, Vol. XVI, No. 1, Januari
}

64 Ibid. 2016, hlm. 19. 
suatu hubungan keluarga. Dalam kondisi inilah dibutuhkan kehadiran hukum keluarga yang memenuhi azas kemanfaatan, keadilan, dan kepastian hukum untuk menjamin hakhak yang timbul akibat adanya hubungan hukum karena perkawinan. Hukum keluarga harus mampu membawa kemaslahatan dalam pelaksanaan atau dalam penegakannya. Selain itu, Aceh yang telah diberikan keistimewaan untuk melaksanakan syariat Islam melalui UU No. 11 Tahun 2006 tentang Pemerintahan Aceh, maka sudah saatnya melahirkan Qanun Aceh tentang Hukum Keluarga yang sesuai dengan filosofi kehidupan masyarakat Aceh dengan menjunjung tinggi nilai-nilai ketuhanan, kemanusiaan, persatuan dan kesatuan, permusyawaratan, serta keadilan. Hukum keluarga yang mengatur dalam bidang perkawinan, perceraian, perwalian, kekuasaan orang tua, dan kewarisan tidak hanya bersifat mengatur saja (fakultatif), tetapi mempunyai upaya paksa (imperatif). Hukum keluarga harus mampu mencegah dan memberikan solusi yang cepat dan tepat dalam berbagai pelanggaran dan kejahatan dalam setiap hubungan keluarga, karena pengingkaran terhadap hak-hak pihak lain dalam suatu hubungan keluarga yang menyebabkan pihak lain menderita dan tersiksa dapat dikategorikan sebagai sebuah pelanggaran atau sebuah kejahatan yang dapat diancam dengan sanksi yang tegas. Kemudian, pengaturan secara khusus melalui Qanun Aceh tentang hukum keluarga sangat memungkinkan karena telah sesuai dengan grand design penerapan syariat Islam yang kaffah di Aceh yang mengatur berbagai aspek, yaitu akidah, syar'iyah, dan akhlak.

\section{DAFTAR PUSTAKA}

\section{A. Buku}

Dimiyati, Khuzaifah, 2004, Teorisasi Hukum Studi Tentang Perkembangan Pemikiran Hukum Di Indonesia 1945-1950, Muhammadyah University Press, Surabaya.

Djubaidah, Neng, 2010, Pencatatan Perkawinan dan Perkawinan Tidak Tercatat Menurut Hukum Tertulis di Indonesia dan Hukum Islam, Sinar Grafika, Jakarta.

Friedmann, 1990, Teori dan Filsafat Hukum, Idealisme Filosofi dan Problema Keadilan (Susunan II), Rajawali Pers, Jakarta.

Jahar, Asep Saepudin, et al., 2013, Hukum Keluarga, Pidana, dan Bisnis, Kencana Prenadamedia Group, Jakarta.

Kartohadiprodjo, Soediman, 1984, Pengantar Tata Hukum di Indonesia, Galdia Indonesia, Jakarta.

Mardani, 2016, Hukum Keluarga Islam di Indonesia, Prenada Media Group, Jakarta.

Mertokusumo, Sudikno, 1988, Mengenal Hukum;
Suatu Pengantar, Liberty, Yogyakarta.

Muhammad, Abdulkadir, 2010, Hukum Perdata Indonesia, Citra Aditya Bakti, Bandung.

Munawwir, Ahmad Warsono, 1997, Al-Munawir: Kamus Arab-Indonesia, Pustaka Progressif, Surabaya.

Suma, Muhammad Amin, 2004, Pengantar Tafsir Ahkam, Rajawali Pers, Jakarta.

Zuhaili, Wahbah, 1989, al-tighat al-Islami wa Adillatuhu, Dar al-Fikr, Bairut.

\section{B. Jurnal}

Abubakar, Alyasa, "Ihwal Perceraian di Indonesia: Perkembangan Pemikiran Dari UndangUndang Perkawinan sampai KHI (Bagian I)", Mimbar Hukum, No. 40 Tahun IX, 1998. Hamdani, Muhammad Faisal, 2016, "Hukum Keluarga Islam Dalam Perspektif HAM Universal (UDHR) dan HAM Islam (UIDHR)", Jurnal Ahkam, Vol. XVI, No. 1, Januari 2016. 
Jamaluddin, 2010, Hukum Perceraian (Dalam Pendekatan Empiris), Pustaka Bangsa Press, Medan.

Mudawam, Syafaul, "Syari'ah-Fiqih-Hukum Islam; Studi tentang Konstruksi Pemikiran Kontemporer”, Jurnal Asy-Syir'ah, Vol. 46 No. II, Juli-Desember 2012.

Muhibbuthabry, "Poligami dan Sanksinya Menurut Perundang-undangan Negara-negara Modern, Jurnal Ahkam, Vol. XVI, No. 1, Januari 2016.

Muslimin, JM., "Hukum Keluarga Islam dalam Potret Interrelasi Sosial", Jurnal Ahkam, Vol. XV, No. 1, Januari 2015.

Nasution, Khoiruddin, “Arah Pembangunan Hukum Keluarga Islam Indonesia: Pendekatan Integratif dan Interkonekstif dalam Membangun Keluarga Sakinah", Jurnal AsySyir'ah, Vol. 46 No. I, Januari-Juni 2012.

Sanusi, Ahmad, "Pelaksanaan Isbat Nikah di Pengadilan Agama Pandeglang", Jurnal Ahkam, Vol. XVI, No. 1, Januari 2016.

\section{Makalah}

Manan, Bagir, "Keabsahan dan Syarat-Syarat Perkawinan Antar Orang Islam Menurut UU No. 1 Tahun 1974", Makalah Seminar Nasional, dengan tema Hukum Keluarga dalam Sistem Hukum Nasional Antara Realitas dan Kepastian Hukum, diselenggarakan oleh Mahkamah Agung Republik Indonesia, Jakarta, 1 Agustus 2009.

\section{Peraturan Perundang-undangan}

Undang-Undang nomor 22 Tahun 1946 tentang Pencatatan Nikah, Talak dan Rujuk.

Undang-Undang No. 32 Tahun 1954 tentang Penetapan Berlakunya Undang-Undang Republik Indonesia Tanggal 21 Nopember 1946 Nomor 22 Tahun 1946 tentang Pencatatan Nikah, Talak Dan Rujuk Di Seluruh Daerah Luar Jawa Dan Madura.

Undang-Undang Nomor 1 Tahun 1974 tentang
Perkawinan (Lembaran Negara Republik Indonesia Tahun 1974 Nomor 1, Tambahan Lembaran Negara Republik Indonesia Nomor 3019).

Undang-Undang Nomor 50 Tahun 2009 tentang Pelayanan Publik merupakan perubahan kedua atas Undang-undang Nomor 7 Tahun 1989 tentang Peradilan Agama (Lembaran Negara Republik Indonesia Tahun 2009 Nomor 159, Tambahan Lembaran Negara Republik Indonesia Nomor 5078).

Kompilasi Hukum Islam.

Peraturan Pemerintah No. 9 Tahun 1975 tentang Pelaksanaan Undang-Undang Nomor 1 Tahun 1974 tentang Perkawinan.

\section{E. Internet}

Serambi Indonesia, "Banyak Isteri Minta Cerai", http://aceh.tribunnews.com/2016/02/14/ banyak-istri-minta-cerai, diakses 18 Agustus 2016.

\section{F. Lain-Lain}

Wawancara dengan Tgk. H. Hanafiah Hamzah, Ketua Majelis Permusyawaratan Ulama Bireuen, tanggal 15 Juli 2014.

Wawancara dengan Abu Mustafa Paloh Gadeng, Ketua Majelis Permusyawaratan Ulama Aceh Utara, tanggal 28 Mei 2014.

Wawancara dengan Tengku Rasyidi, Ketua Majelis Permusyawaratan Ulama Pidie, tanggal 19 Mei 2014.

Wawancara dengan Abu Mustafa Paloh Gadeng, Ketua Majelis Permusyawaratan Ulama Aceh Utara, tanggal 28 Mei 2014.

Wawancara dengan Tgk. Heli Imran, Anggota Majelis Permusyawaratan Ulama Bireuen, tanggal 15 Juli 2014.

Wawancara Syahrizal Abbas, Kepala Dinas Syariat Islam Provinsi Aceh, tanggal 20 Januari 2015. Wawancara dengan Zulkifli, Kepala Kantor Urusan Agama Kecamatan Senagan, Nagan Raya, tanggal 21 Agustus 2015. 